\title{
SISTEM NOTIFIKASI SMS HASIL PREDIKSI SAHAM/FOREX MENGGUNAKAN RASPBERRY PI
}

\author{
Kennardi Dewanto Tiono ${ }^{1}$, Murtiyanto Santoso ${ }^{2}$, Raymond Sutjiadi ${ }^{3}$, Resmana Lim ${ }^{4}$ \\ ${ }^{1,2,4}$ Program Studi Teknik Elektro, Universitas Kristen Petra \\ ${ }^{3}$ Program Studi Teknik Informatika, Institut Informatika Indonesia \\ Email: ${ }^{1}$ kennardi1996@gmail.com; ${ }^{2}$ murtis@petra.ac.id; ${ }^{3}$ raymond@ikado.ac.id; ${ }^{4}$ resmana@petra.ac.id
}

(Naskah masuk: 15 Oktober 2018, diterima untuk diterbitkan: 18 Desember 2018)

\begin{abstract}
Abstrak
Proyek ini dimaksudkan untuk membuat sebuah sistem yang dapat menganalisa dan membuat prediksi trend harga naik atau turun dari sebuah pasar saham, dan mengirimkan notifikasi SMS mengenai hasil prediksi kepada para pengguna. Sistem memanfaatkan Raspberry Pi yang dikoneksikan dengan Internet serta sebuah modul GSM untuk keperluan pengiriman hasil notifikasi SMS. Langkah-langkah yang dilakukan untuk dapat membuat sistem yang dimaksud adalah dengan membuat program untuk proses analisa dan prediksi serta proses notifikasi, merancang dan membuat tampilan halaman web untuk user profile, dan menguji coba kelayakan dari program-program yang sudah dibuat. Dari hasil percobaan diketahui bahwa sistem yang telah dibuat mampu membuat analisa prediksi harga pasar saham serta menggunakan hasil dari prediksi tersebut untuk mengirimkan notifikasi berupa SMS kepada para user.
\end{abstract}

Kata kunci: notifikasi sms, raspberry pi, prediksi saham/forex

\section{SMS BASED NOTIFICATION SYSTEM FOR STOCK/FOREX PREDICTION USING RASPBERRY PI}

\begin{abstract}
This project is intended to create a system that can analyze and predict price trends up or down from a stock market, and send SMS notifications about the results of predictions to users. The system utilizes a Raspberry Pi that is connected to the Internet and a GSM module for sending SMS notification results. The steps taken to create the system in question is to create a program for the analysis and prediction process and notification process, design and create a web page display for the user profile, and test the feasibility of the programs that have been made. From the experimental results it is known that the system that has been made is able to analyze stock market price predictions and use the results of these predictions to send notifications in the form of SMS to users.
\end{abstract}

Keywords: sms notification, raspberry pi, stock/forex prediction

\section{PENDAhUluAN}

Perkembangan teknologi informasi saat ini sudah mulai mempengaruhi kegiatan dunia bisnis saham. Hal ini dapat dilihat dari munculnya kabar yang diulas pada sebuah artikel oleh Cade di website WIRED. Pada artikel tersebut, Cade menjabarkan tentang penggunaan program berbasis Artificial Intelligence untuk melakukan analisa dan memprediksi harga saham pada beberapa hari ke depan yang dilakukan oleh seorang pakar bidang Artificial Intelligence (AI) bernama Ben Goertzel (Metz, 2016). Kemunculan dari program untuk memprediksi harga saham, baik yang menggunakan AI maupun tidak, dapat membawa pengaruh dimana orang akan cenderung menggunakan program untuk memprediksi harga saham. Hal ini dikarenakan menggunakan program dipandang lebih efisien dan beroperasi berdasarkan algoritma dan data yang ada sehingga prediksi yang dihasilkan memiliki tingkat kesalahan yang kecil.

Namun, penggunaan dari program tersebut memunculkan masalah baru, yaitu ketika hasil prediksi dari program sudah keluar, para pengguna tidak selalu berada di depan perangkat untuk melihat hasilnya lantaran memiliki kesibukan di tempat lain. Hal ini dikarenakan program untuk melakukan analisa dan membuat prediksi masih memerlukan perangkat dengan kemampuan memproses data yang cukup tinggi. Selain itu, prediksi harga saham dihasilkan dengan cara melakukan analisa harga saham di waktu lampau secara berulang sehingga dapat memakan waktu cukup lama tergantung dari 
jumlah data yang diproses. Akibatnya, program tersebut hanya dapat dijalankan di perangkat dengan kemampuan processing data yang tinggi seperti laptop atau PC.

Dari permasalahan tersebut, solusi yang dapat dilakukan adalah membuat sebuah sistem yang dapat menyimpan hasil prediksi harga saham dan memberikan notifikasi kepada pengguna program melalui fungsi SMS pada telepon genggam. Solusi tersebut didasarkan pada kondisi masyarakat saat ini yang sebagian besar sudah dapat memiliki akses untuk menggunakan smartphone. Walaupun memiliki kemampuan memproses data yang masih belum dapat menyamai $\mathrm{PC}$, sebuah smartphone memiliki fitur SMS yang dapat menerima pesan berbentuk teks hampir di mana saja selama masih terdapat sinyal komunikasi. Dengan menggunakan fitur SMS tersebut, maka sistem dapat memberitahu pengguna bahwa hasil prediksi harga saham sudah keluar dan dapat melihatnya di mana saja melalui aplikasi web browser di smartphone mereka menggunakan link alamat web yang terdapat di dalam isi pesan.

Sistem notifikasi melalui media SMS sudah mulai diterapkan di beberapa perusahaan analisa saham/forex. Salah satu perusahaan yang mulai menerapkan sistem tersebut adalah perusahaan bernama ForexSignal. Perusahaan ini adalah salah satu perusahaan analisa dan jual beli saham/forex yang sudah menerapkan sistem notifikasi melalui sistem SMS (ForexSignal, 2016).

Dalam pelaksanaan Proyek ini, sistem akan dikembangkan dengan menggunakan Raspberry Pi sebagai controller utama dan sebuah modul GSM sebagai media komunikasi untuk mengirimkan pesan. Pesan tersebut dikirim menuju smartphone pemilik dalam format SMS dimana terdapat link dalam format HTML untuk mengakses database di dalamnya. Melalui link tersebut, pemilik dapat langsung melihat grafik hasil prediksi dari program yang ditampilkan pada sebuah halaman web melalui aplikasi web browser di smartphone mereka.

\section{PERENCANAAN SISTEM}

Sistem dirancang dengan menggunakan Raspberry Pi sebagai controller serta modul GSM sebagai media pengiriman notifikasi sms kepada para user seperti Gambar 1. Raspberry pi terhubung ke Internet melalui saluran Ethernet yang digunakan untuk mengakses data harga samah/forex via Yahoo Finance. Pada bagian perangkat lunak, sistem dibuat dengan menggunakan bahasa Python dan Django yang dimana memiliki konsep desain sistem sebagai berikut:

Sistem ini menggunakan sebuah database bernama user database dimana berisi tabel mengenai profil para user dengan nama tabel auth_user. Jenis data yang disimpan adalah nama user, email, alamat, password, preferensi pasar saham/Forex yang diinginkan, dan nomor kontak telepon yang nantinya akan dipakai sebagai alamat pengiriman pesan.

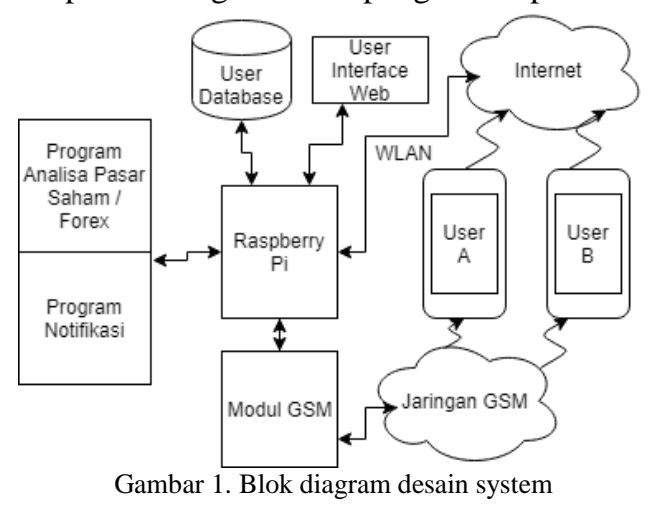

Profil user yang terdapat di tabel ini dapat diubah sesuai dengan kebutuhan pemiliknya melalui sebuah halaman web user interface yang dibuat dengan menggunakan Django. Django sendiri merupakan sebuah software web framework untuk digunakan bersama permograman Python (Sianipar \& Wadi, 2015).

Cara kerja dari sistem ini diawali dengan menjalankan program analisa terlebih dahulu dimana program akan mengambil data tabel suatu pasar saham dari website Yahoo Finance. Selanjutnya, program akan menganalisa satu pasar saham/ Forex yang sudah ditentukan sebelumnya dengan menggunakan metode membandingkan dua SMA (simple moving average), dimana yang satu merupakan SMA jangka pendek, sedangkan yang lain adalah SMA jangka panjang (Gunasekarage \& Power, 2001). Hasil analisa yang dikeluarkan ada dua. Yang pertama berbentuk sebuah sinyal yang muncul ketika terjadi persilangan antara kedua SMA pada periode hari terakhir dari data yang diambil atau yang disebut crossing signal. Hasil yang kedua adalah sebuah grafik yang menunjukkan hasil prediksi. Setelah membuat sebuah analisa prediksi daham/forex, program akan meyimpan grafik hasil prediksi saham/Forex dalam bentuk gambar yang disimpan ke dalam folder static pada program untuk halaman web user interface. Setelah program analisa menyimpan hasil prediksi, langkah selanjutnya adalah memeriksa hasil keluaran dari sinyal dimana jika terdapat dua sinyal pada data SMA di dua hari terakhir, maka program akan secara otomatis menjalankan program pengiriman notifikasi.

Pada saat program notifikasi dijalankan, pertama Kali Raspberry Pi akan mengakses tabel user profile pada user database dan mengambil semua catatan record yang ada. Selanjutnya program notifikasi akan mencoba untuk berkomunikasi dengan modul GSM dan menyusun sebuah string yang nanti akan dikirim berisi data nama dari user, tanggal prediksi, hasil analisa secara singkat, dan sebuah teks tautan menuju halaman web yang menampilkan grafik hasil prediksi. Untuk data hasil analisa diperoleh dengan melihat jenis crossing signal yang dihasilkan pada data SMA hari terakhir. Bila 
pada tanggal tersebut crossing signal mengeluarkan angka 1, maka program akan memprediksikan kondisi 'Buy' untuk hasil analisa pasar saham di hari itu. Begitu juga sebaliknya jika sinyal mengeluarkan angka -1, maka program akan mengumumkan hasil prediksi berupa kondisi 'Sell'.

Untuk bagian perangkat keras, rangkaian yang dibuat terdiri atas Raspberry Pi dan modul GSM dimana antara Raspberry Pi dan modul GSM SIM800L terhubung dengan menggunakan komunikasi serial seperti pada gambar di bawah ini:

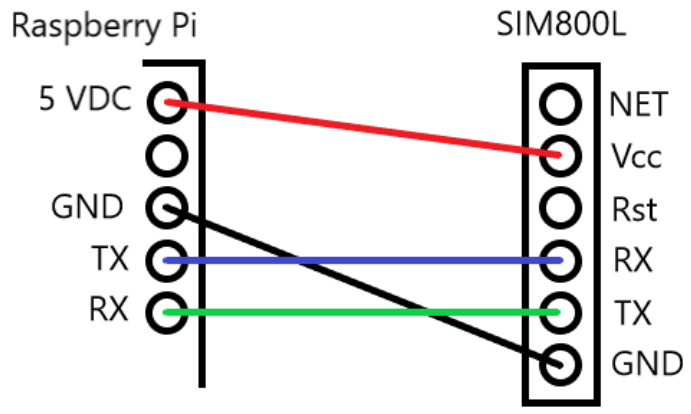

Gambar 2. Skema blok diagram desain perangkat keras

Secara singkat, Gambar 1 dapat dibagi menjadi 4 bagian, yaitu:

1. Halaman Web Profil User

2. Program Pembangkit Sinyal Prediksi Saham/Forex

3. Program Notifikasi

4. Halaman Web Tampilan Hasil Prediksi

\section{A. Halaman Web Profil User}

Merupakan bagian dari sistem berbentuk halaman web yang dirancang untuk para user menggunakan bahasa Python, Django, dan sebuah database. Bagian ini berfungsi memungkinkan para user untuk dapat mendaftarkan diri mereka ke dalam sebuah tabel bernama 'auth_user' pada database server, melakukan edit pada profil mereka, dan mengganti jenis pasar saham yang ingin diprediksi oleh sistem. Berikut adalah tabel yang mendeskripsikan struktur dari tabel 'auth_user' dan gambar use case diagram dari halaman web profile user:

Tabel 1. Struktur tabel auth_user

\begin{tabular}{lccc}
\hline \multicolumn{1}{c}{ Field } & Type & Key & Default \\
\hline Username & Varchar(20) & Unique & Null \\
Password & Varchar(128) & - & Null \\
Email & Varchar(25) & - & Null \\
Phone & Varchar(15) & - & Null \\
$\begin{array}{l}\text { Number } \\
\text { Stock Market }\end{array}$ & Varchar(5) & - & Null \\
Pref & & & \\
\hline
\end{tabular}

Kennardi Dewanto Tiono, dkk, Sistem Notifikasi SMS 115

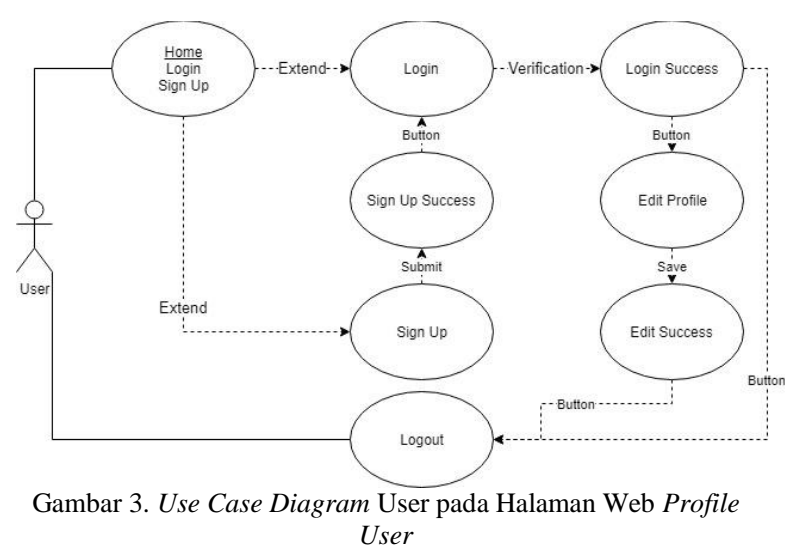

B. Program Pembangkit Sinyal Prediksi

Merupakan bagian dari sistem yang berfungsi untuk menganalisa data harga suatu pasar saham dari website Yahoo Finance, lalu membuat prediksi dari hasil analisa tersebut menggunakan pandas dan matplotlib (Efstathopoulos, t.thn.).

Secara garis besar, proses kerja dari program ini adalah sebagai berikut:

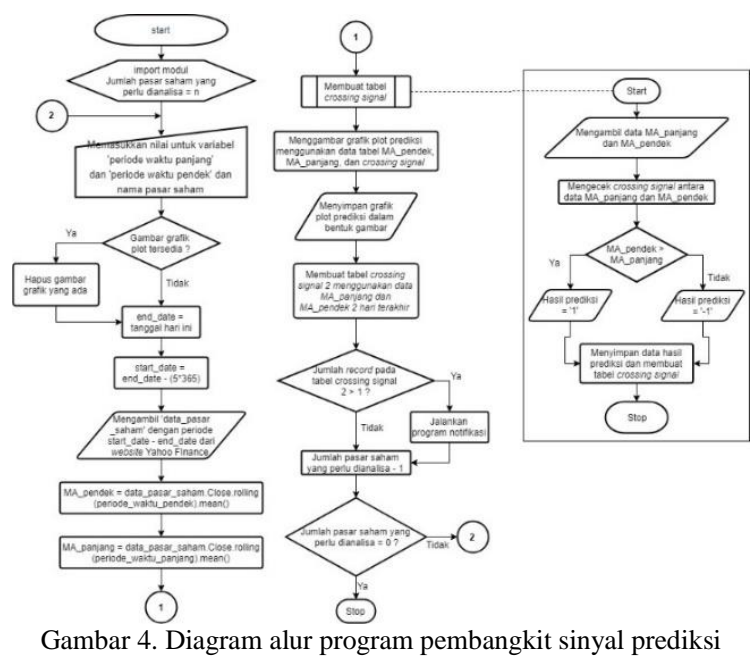

Metode yang digunakan untuk menganalisa dan membuat prediksi harga pasar saham adalah metode perbandingan antara 2 jenis data simple moving average atau SMA dari data harga pasar saham dimana yang satu merupakan data SMA jangka panjang sedangkan yang lain adalah SMA jangka pendek. Prinsip perbandingan yang digunakan adalah ketika terjadi persilangan antara kedua data SMA, jika data SMA pendek sebelum persilangan lebih besar dari SMA panjang, maka program akan mengumum-kan hasil prediksi berupa 'Sell'. Begitu juga sebaliknya jika data SMA pendek lebih kecil, maka hasil prediksi yang dikeluarkan adalah 'Buy'.

Berikut adalah contoh hasil analisa menggunakan metode SMA: 


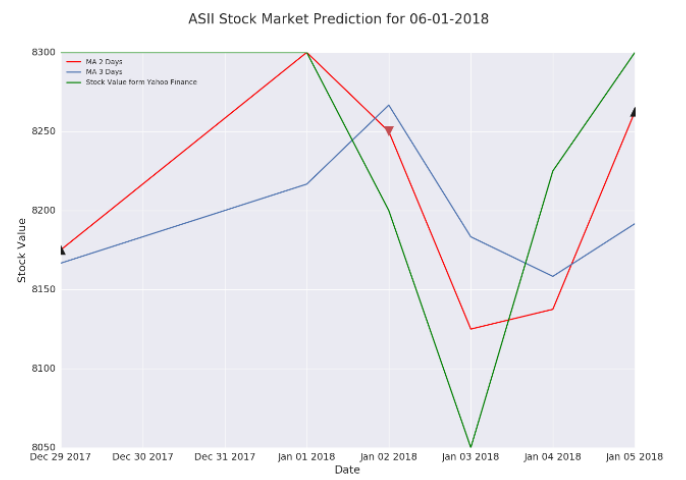

Gambar 5. Contoh hasil analisa pasar saham dengan metode SMA

\section{Program Notifikasi}

Merupakan bagian dari sistem yang bertugas dalam mengirimkan sebuah pesan notifikasi dalam format SMS ke perangkat seluler milik para user. Bagian ini memerlukan akses dengan tabel 'auth_user' pada database agar program dapat mengetahui alamat nomor telepon dari user yang sudah terdaftar. Berikut adalah algoritma, blok kode pemrograman, dan diagram time sequence dari program notifikasi:

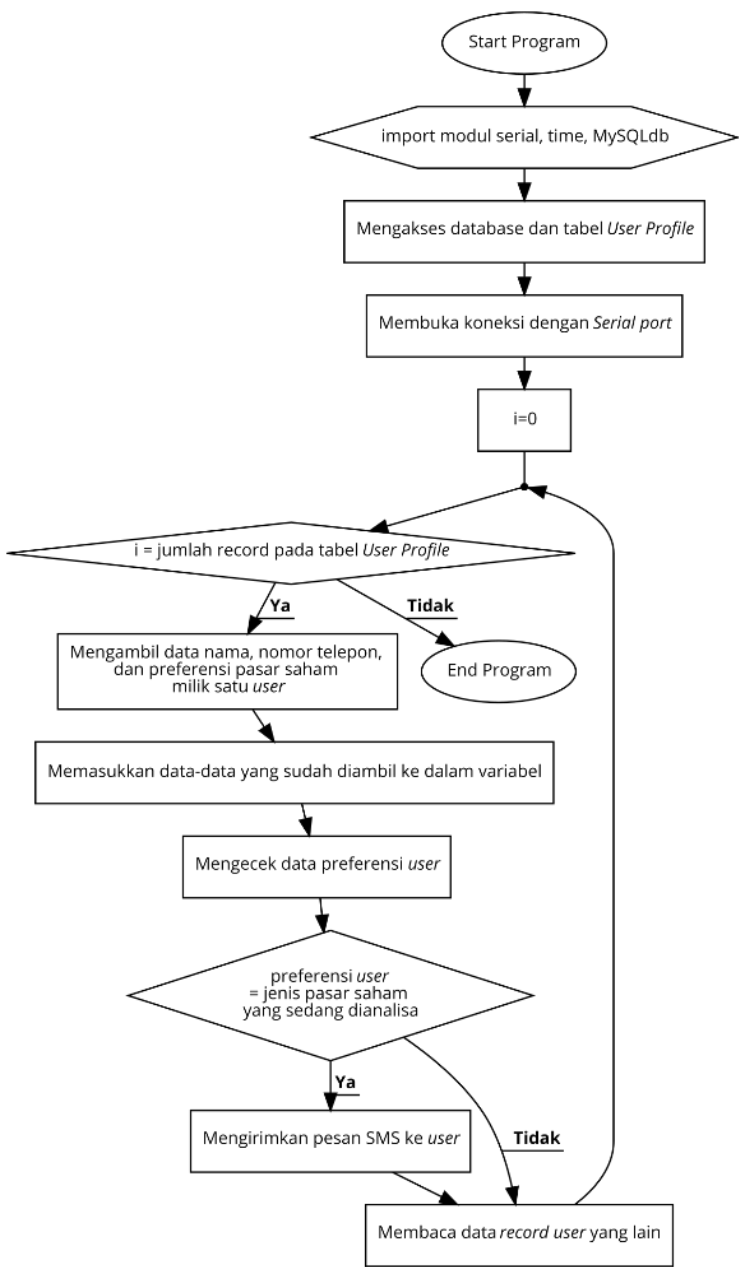

Gambar 6. Diagram alur program notifikasi
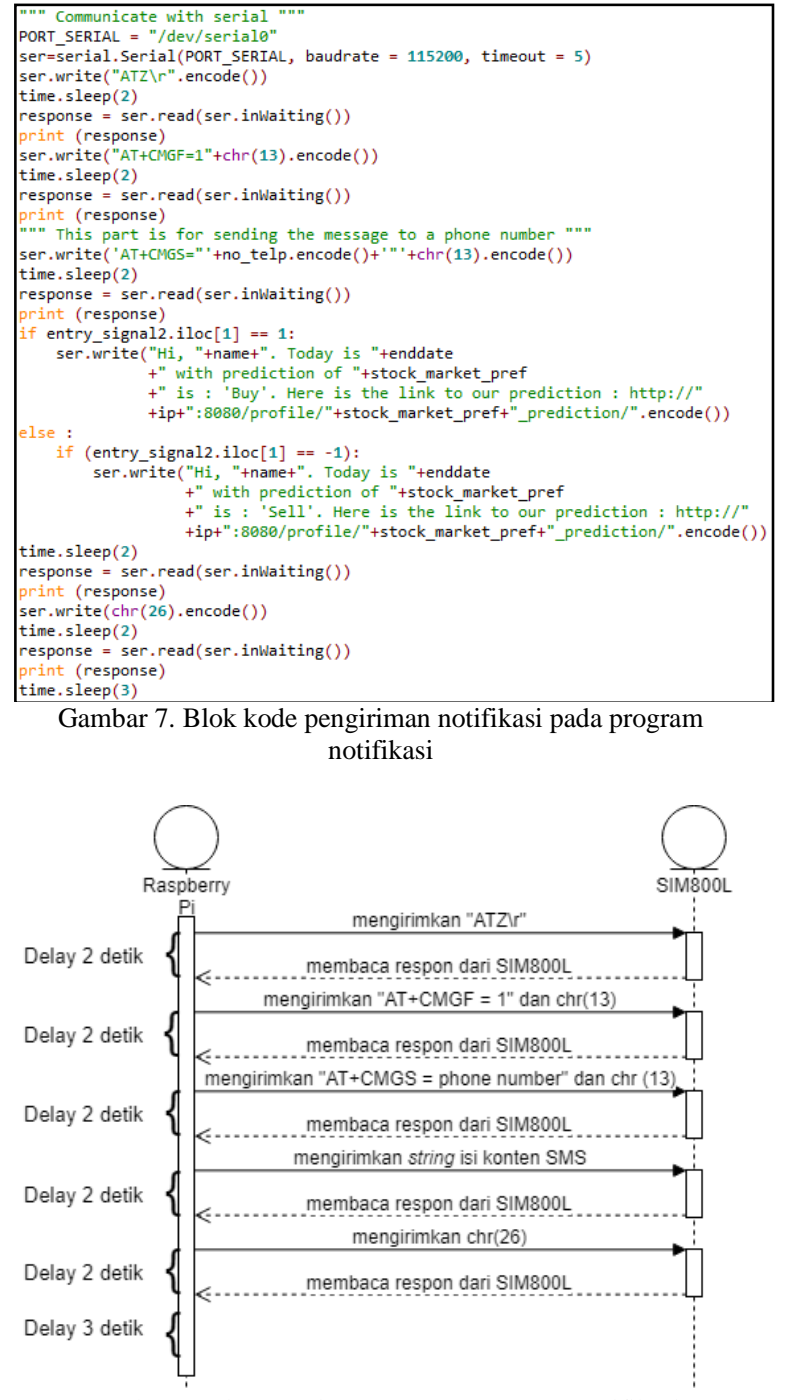

Gambar 8. Diagram time sequence program notifikasi

\section{Halaman Web Hasil Prediksi}

Merupakan bagian dari sistem berfungsi untuk menampilkan gambar grafik berisi prediksi perubahan harga saham pada pasar saham tertentu kepada para user. Gambar grafik diperoleh dari folder static pada program halaman web profile user. Berikut adalah desain tampilan dari halaman web hasil prediksi:

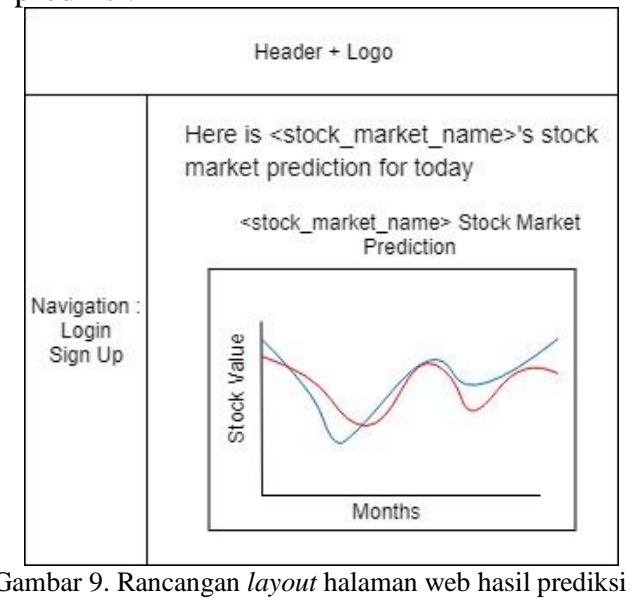




\section{PENGUJIAN SISTEM DAN ANALISA}

\section{A. Spesifikasi Kebutuhan Perangkat Keras}

Untuk dapat mengoperasikan sistem, maka perangkat Raspberry $\mathrm{Pi}$ yang akan digunakan memiliki spesifikasi perangkat keras dengan kriteria sebagai berikut:

$\begin{array}{ll}\text { Nama Seri } & : \text { Raspberry Pi } 2 \text { model B } \\ \text { Processor } & : 900 \mathrm{MHz} \\ \text { Memory RAM } & : 1 \mathrm{~GB} \\ \text { Memory Eksternal } & : \text { 32 GB } \\ \text { Modul tambahan } & : \text { SIM800L } \\ \text { Nama ISP } & \text { : Indosat }\end{array}$

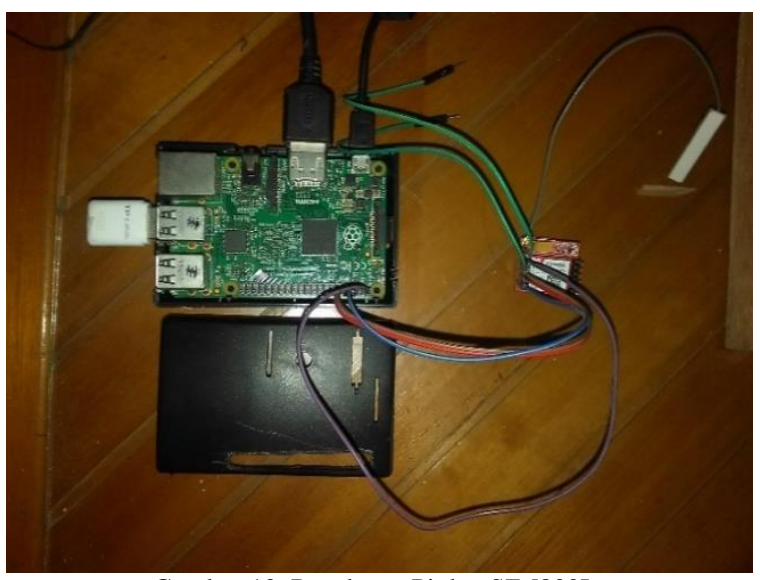

Gambar 10. Raspberry Pi dan SIM800L

\section{B. Pengujian Tampilan Halaman Web User Profile}

Pengujian yang dilakukan dengan cara simulasi login, registrasi user, dan mengubah data salah satu user. Berikut adalah gambar hasil simulasi pengujian:
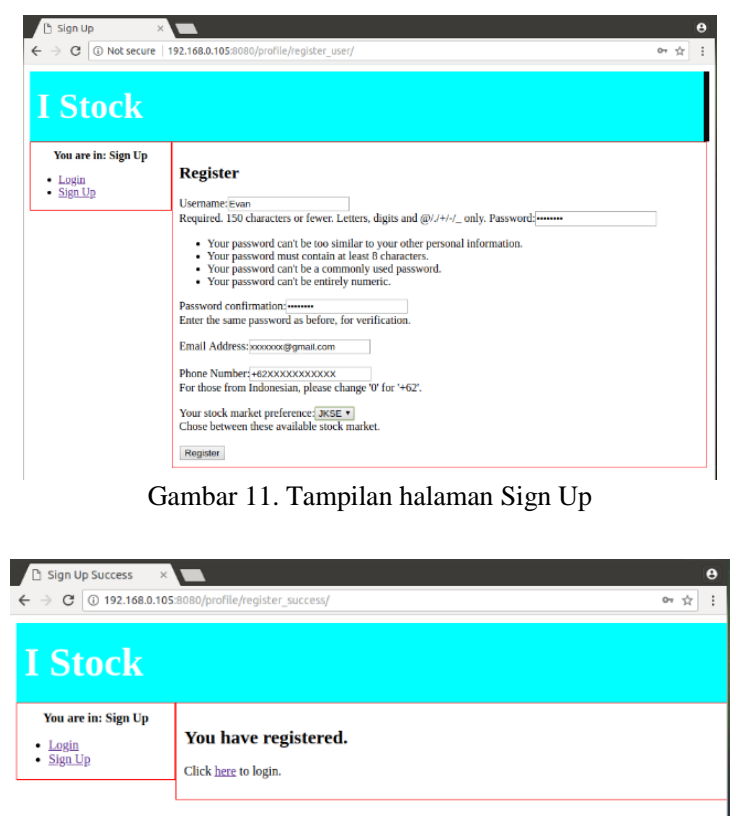

Gambar 12. Tampilan halaman Sign Up Success

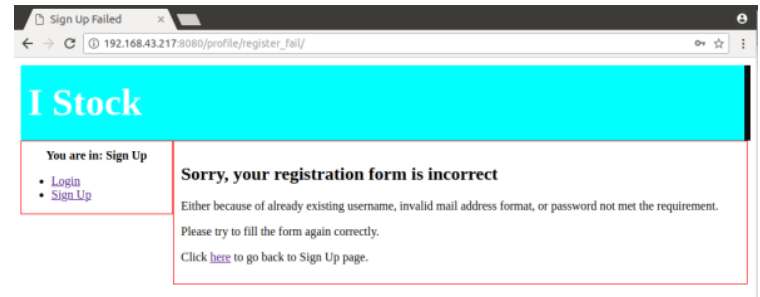

Gambar 13. Tampilan halaman Sign Up Failed
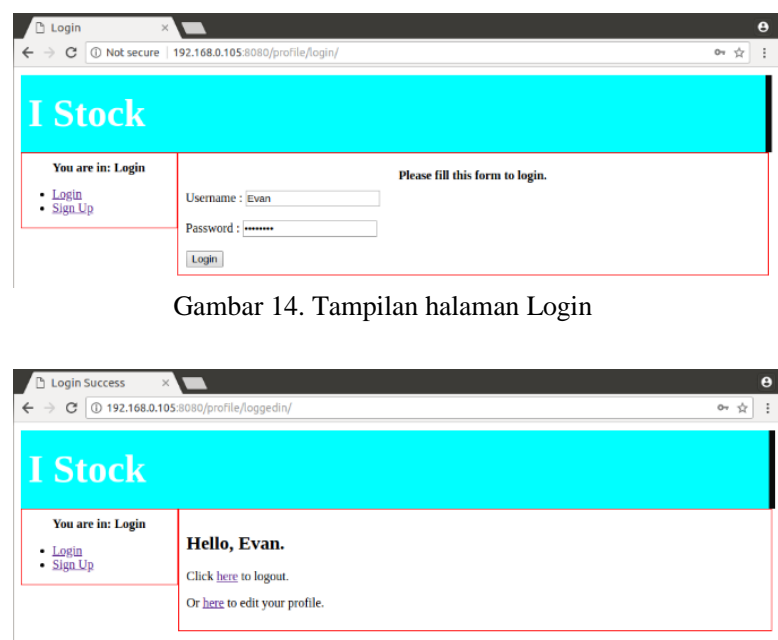

Gambar 15. Tampilan halaman Login Success

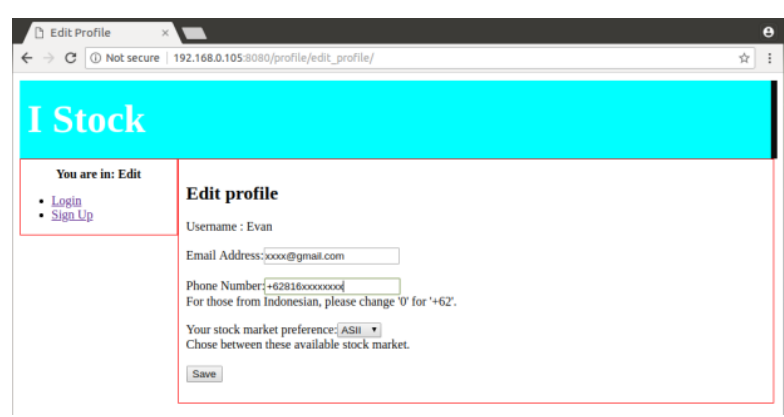

Gambar 16. Tampilan halaman Edit Profile

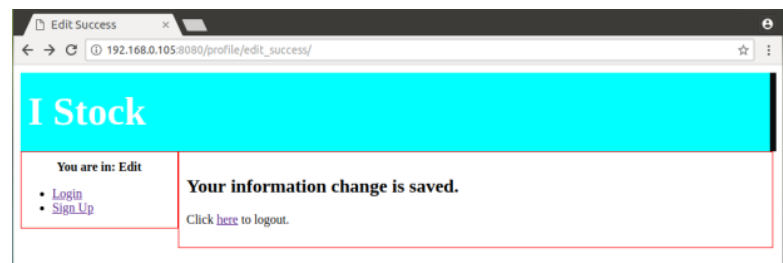

Gambar 17. Tampilan halaman Edit Success

\section{Pengujian Program Penghasil Sinyal Prediksi}

Pengujian program pembangkit sinyal prediksi dilakukan dengan membuat analisa dan prediksi harga pasar saham dari 2 jenis pasar saham dengan nama ASII dan JKSE menggunakan data saham yang diperoleh dari website https://finance.yahoo.com/. Pengujian dibagi menjadi 2 jenis, yaitu pengujian backtest dan pengujian forward test. 


\section{(1) Pengujian Backtest}

Pada percobaan backtest, program akan membuat prediksi harga pasar saham untuk tanggal 2 Januari 2018 sampai 6 Januari 2018. Pengujian backtest untuk program pembangkit sinyal prediksi dilakukan melalui 2 tahap. Tahap pertama dilakukan menggunakan metode simple moving average dimana untuk SMA pendek menggunakan periode 2 hari, dan SMA Panjang menggunakan periode 3 hari. Tahap kedua juga dilakukan dengan menggunakan metode simple moving average, namun untuk kali ini SMA pendek menggunakan periode 5 hari, dan SMA Panjang menggunakan periode 10 hari.

Berikut adalah hasil dari kedua pengujian backtest dari program penghasil sinyal prediksi yang dilaksanakan pada tanggal 5 Juni 2018 jam 14.00:

Tabel 2. Hasil Pengujian Backtest Pertama Program Penghasil Sinyal Prediksi untuk Pasar Saham ASII

\begin{tabular}{|c|c|c|c|c|c|}
\hline \multirow{2}{*}{ Tanggal } & \multicolumn{3}{|c|}{ Kondisi pada data terakhir } & \multirow{2}{*}{$\begin{array}{c}\text { Kondisi Real dari } \\
\text { Sumber }\end{array}$} & \multirow{2}{*}{ Ket. } \\
\hline & Nilai Hasil Prediksi & $\begin{array}{l}\text { Kondisi } \\
\text { crossing }\end{array}$ & Kondisi Realita & & \\
\hline 2 Januari 2018 & 1 & - & Hold (Buy) & Turun & Meleset \\
\hline 3 Januari 2018 & -1 & $\checkmark$ & Sell & Turun & Sesuai \\
\hline 4 Januari 2018 & -1 & - & Hold (Sell) & Naik & Meleset \\
\hline 5 Januari 2018 & -1 & - & Hold (Sell) & Naik & Meleset \\
\hline 6 Januari 2018 & 1 & $\checkmark$ & Buy & Naik & Sesuai \\
\hline
\end{tabular}

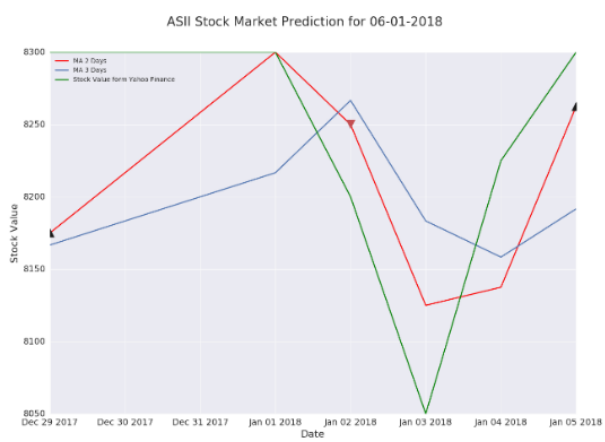

Gambar 18. Grafik hasil percobaan backtest pertama program penghasil sinyal untuk prediksi pasar ASII tanggal 6 Januari 2018

Tabel 3. Hasil Pengujian Backtest Pertama Program Penghasil Sinyal Prediksi untuk Pasar Saham JKSE

\begin{tabular}{cccccc}
\hline \multirow{2}{*}{ Tanggal } & \multicolumn{3}{c}{ Kondisi pada data terakhir } & \multicolumn{2}{c}{$\begin{array}{c}\text { Kondisi Real dari } \\
\text { Sumber }\end{array}$} \\
\cline { 2 - 5 } & Nilai Hasil Prediksi & $\begin{array}{c}\text { Kondisi } \\
\text { crossing }\end{array}$ & Kondisi Realita & Hold (Buy) & Turun \\
\hline 2 Januari 2018 & 1 & - & Hold (Buy) & Turun \\
3 Januari 2018 & 1 & - & Sell & Neleset \\
4 Januari 2018 & -1 & $\checkmark$ & Hold (Sell) & Meleset \\
5 Januari 2018 & -1 & - & Buy & Meleset \\
6 Januari 2018 & 1 & $\checkmark$ & Sesuai \\
\hline
\end{tabular}

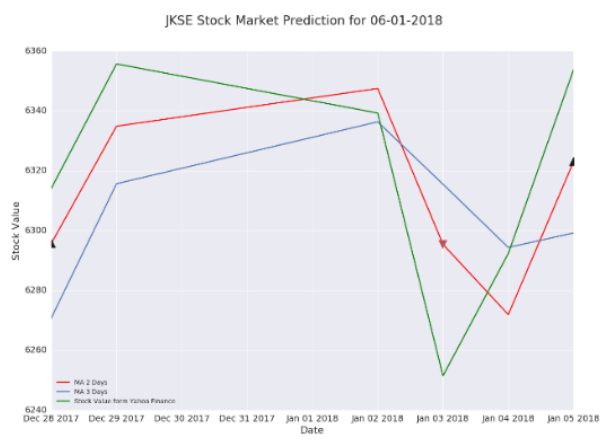


Tabel 4. Hasil Pengujian Backtest Kedua Program Penghasil Sinyal Prediksi untuk Pasar Saham ASII

\begin{tabular}{cccccc}
\hline \multirow{2}{*}{ Tanggal } & \multicolumn{2}{c}{ Kondisi pada data terakhir } & \multicolumn{2}{c}{$\begin{array}{c}\text { Kondisi Real dari } \\
\text { Sumber }\end{array}$} \\
\cline { 2 - 5 } & Nilai Hasil Prediksi & $\begin{array}{c}\text { Kondisi } \\
\text { crossing }\end{array}$ & Kondisi Realita & Hold (Buy) & Turun \\
\hline 2 Januari 2018 & 1 & - & Hold (Buy) & Turun & Meleset \\
3 Januari 2018 & 1 & - & Hold (Buy) & Naik \\
4 Januari 2018 & 1 & - & Hold (Buy) & Naik & Sesuai \\
5 Januari 2018 & 1 & - & Hold (Buy) & Naik & Sesuai \\
6 Januari 2018 & 1 & - & & & \\
\hline
\end{tabular}

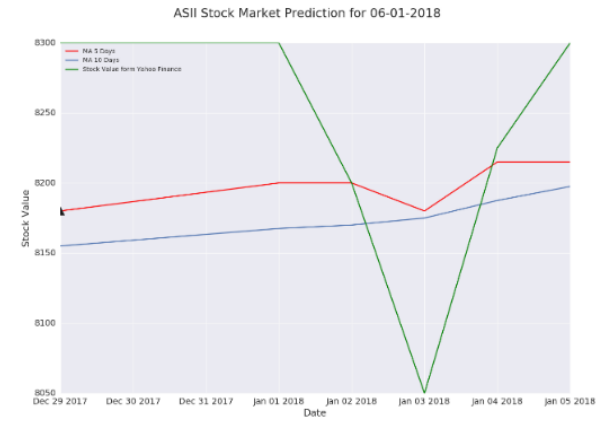

Gambar 20. Grafik hasil percobaan backtest kedua program penghasil sinyal untuk prediksi pasar ASII tanggal 6 Januari 2018

Tabel 5. Hasil Pengujian Backtest Kedua Program Penghasil Sinyal Prediksi untuk Pasar Saham JKSE

\begin{tabular}{|c|c|c|c|c|c|}
\hline \multirow[b]{2}{*}{ Tanggal } & \multicolumn{3}{|c|}{ Kondisi pada data terakhir } & \multirow[b]{2}{*}{$\begin{array}{c}\text { Kondisi Real dari } \\
\text { Sumber }\end{array}$} & \multirow[b]{2}{*}{ Keterangan } \\
\hline & Nilai Hasil Prediksi & $\begin{array}{l}\text { Kondisi } \\
\text { crossing }\end{array}$ & Kondisi Realita & & \\
\hline 3 Januari 2018 & 1 & - & Hold (Buy) & Turun & Meleset \\
\hline 4 Januari 2018 & 1 & - & Hold (Buy) & Naik & Sesuai \\
\hline
\end{tabular}

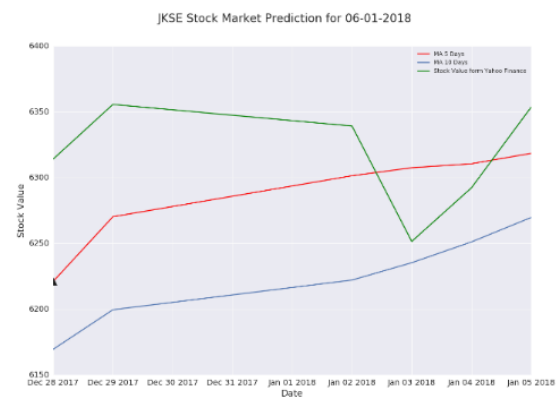

Gambar 21. Grafik hasil percobaan backtest kedua program penghasil sinyal untuk prediksi pasar JKSE tanggal 6 Januari 2018

(2)

\section{Pengujian Forward Test}

Pada percobaan backtest, program akan membuat prediksi harga pasar saham secara real dimana program akan dijalankan pada jam 06.40 setiap hari dimulai dari tanggal 4 Juni 2018 sampai tanggal 6 Juni 2018. Berikut adalah tabel-tabel hasil pengujian forward test dari program penghasil sinyal prediksi:

Tabel 6. Hasil Pengujian Forward Test Program Penghasil Sinyal Prediksi untuk Pasar Saham ASII

\begin{tabular}{cccccc}
\hline \multirow{2}{*}{ Tanggal } & \multicolumn{2}{c}{ Kondisi pada Data Tanggal Terakhir } & & Kondisi Real dari Sumber & Keterangan \\
\cline { 2 - 3 } & Nilai Hasil Prediksi & $\begin{array}{c}\text { Kondisi } \\
\text { crossing }\end{array}$ & Kondisi Realita & Told (Sell) & Turun \\
\hline 4 Juni 2018 & -1 & - & Buy & Naik & Sesuai \\
5 Juni 2018 & 1 & $\checkmark$ & Turun & Mesuai \\
6 Juni 2018 & 1 & - & Hold (Buy) & Melet \\
\hline
\end{tabular}




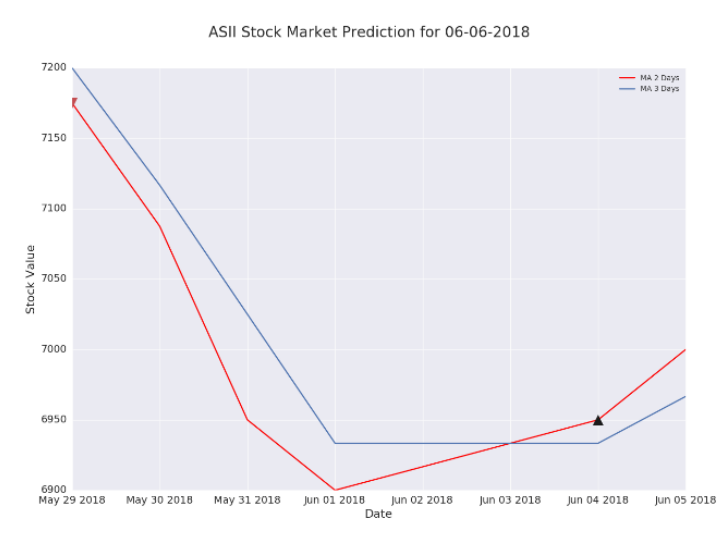

Gambar 22. Grafik hasil percobaan forward test program penghasil sinyal untuk prediksi pasar ASII tanggal 6 Juni 2018

Tabel 7. Hasil Pengujian Forward Test Program Penghasil Sinyal Prediksi untuk Pasar Saham JKSE

\begin{tabular}{|c|c|c|c|c|c|}
\hline \multirow[b]{2}{*}{ Tgl } & \multicolumn{3}{|c|}{$\begin{array}{c}\text { Kondisi pada Data Tanggal } \\
\text { Terakhir }\end{array}$} & \multirow{2}{*}{$\begin{array}{c}\text { Kondisi } \\
\text { Real } \\
\text { dari } \\
\text { Sumber }\end{array}$} & \multirow[b]{2}{*}{ Ket } \\
\hline & $\begin{array}{c}\text { Nilai } \\
\text { Hasil } \\
\text { Prediksi }\end{array}$ & $\begin{array}{l}\text { Kondisi } \\
\text { crossing }\end{array}$ & $\begin{array}{l}\text { Kondisi } \\
\text { Realita }\end{array}$ & & \\
\hline $\begin{array}{c}4 \\
\text { Juni } \\
2018\end{array}$ & -1 & - & $\begin{array}{l}\text { Hold } \\
\text { (Sell) }\end{array}$ & Turun & Sesuai \\
\hline $\begin{array}{c}5 \\
\text { Juni } \\
2018\end{array}$ & -1 & - & $\begin{array}{l}\text { Hold } \\
\text { (Sell) }\end{array}$ & Naik & Meleset \\
\hline $\begin{array}{c}6 \\
\text { Juni } \\
2018\end{array}$ & 1 & $\checkmark$ & Buy & Turun & Meleset \\
\hline
\end{tabular}

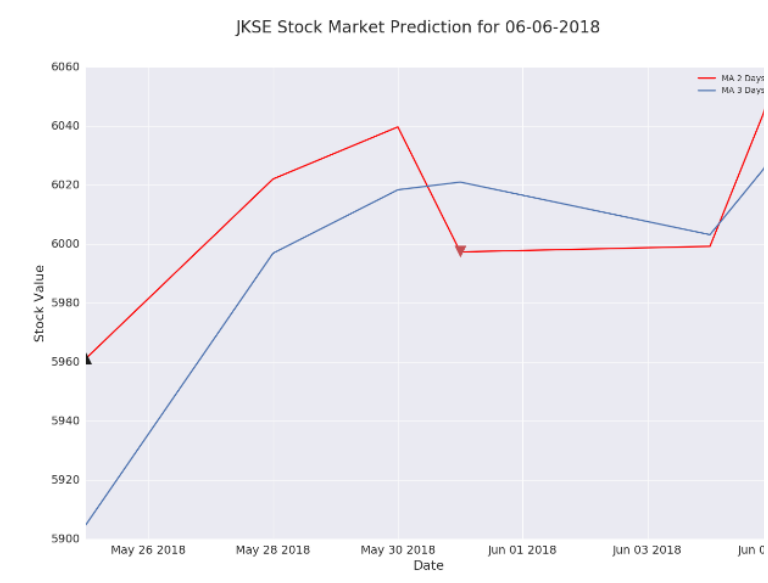

Gambar 23. Grafik hasil percobaan forward test program penghasil sinyal untuk prediksi pasar JKSE tanggal 6 Juni 2018

\section{Pengujian Program Notifikasi}

Pengujian program notifikasi dapat dibagi menjadi 2 jenis, dimana yang pertama adalah pengujian performa kinerja dari program notifikasi, dan pengujian setelah proses integrasi antara program notifikasi dengan program pembangkit sinyal prediksi.

\section{(1) Pengujian Performa}

Pengujian performa dilakukan dengan tujuan mengetahui seberapa lama waktu yang diperlukan oleh program notifikasi untuk mengirimkan SMS kepada para user dalam jumlah cukup banyak untuk satu jenis pasar saham. . Percobaan ini dilakukan dengan cara menjalankan program notifikasi untuk mengirimkan SMS ke semua user yang ada pada tabel di database dan dilakukan berulang sebanyak 3 kali.

Untuk pelaksanaan pengujian ini, program notifikasi sudah diatur dengan spesifikasi dimana komunikasi dengan modul GSM dijalankan dengan menggunakan nilai baud rate sebesar 115.200 bps dan pada setiap proses komunikasi antara Raspberry Pi dengan modul GSM diberi delay selama 2 detik dan 3 detik untuk setelah proses komunikasi yang terakhir sehingga lama durasi pengiriman tiap user adalah 13 detik. Selain itu, untuk percobaan ini juga telah disediakan 10 dummy user yang sudah disusun berurutan. Kesepuluh user tersebut akan digunakan untuk menjalankan percobaan ini dengan menggunakan data preferensi saham yang sama, yaitu pasar saham ASII. Berikut adalah tabel hasil pengujian perforam dari program notifikasi:

Tabel 8. Hasil Uji Coba Performa dari Program Notifikasi

\begin{tabular}{ccc}
$\begin{array}{c}\text { Percobaan } \\
\text { ke- }\end{array}$ & $\begin{array}{c}\text { Jumlah User yang } \\
\text { Menerima SMS }\end{array}$ & $\begin{array}{c}\text { Total Waktu } \\
\text { Pengiriman } \\
\text { (detik) }\end{array}$ \\
\hline I & 10 & 134 \\
II & 10 & 137 \\
III & 10 & 136 \\
\hline
\end{tabular}

Dari Tabel 8, terlihat bahwa dibutuhkan waktu kurang lebih antara 134-137 detik untuk mengirimkan SMS kepada 10 user. Dari hasil tersebut dapat disimpulkan bahwa program notifikasi dapat mengirimkan SMS kepada para user dengan jumlah kurang lebih sekitar 266,66 user, atau jika dibulatkan ke satuan terkecil menjadi 266 user dalam waktu 1 jam.

\section{(2) \\ Pengujian Integrasi Program Notifikasi dengan Program Pembangkit Sinyal}

Pengujian program yang sudah diintegrasikan dilakukan bersamaan dengan pengujian program penghasil sinyal prediksi dimana program akan memilah data hasil keluaran dari program pembangkit sinyal prediksi, mengambil semua data record yang tersimpan di dalam tabel 'auth_user', dan mengirimkan notifikasi kepada setiap user sesuai dengan data preferensi pasar saham dari tiap user. Jumlah record yang akan digunakan pada percobaan ini adalah 5 user yang dimana dengan variasi data preferensi pasar saham sebagai berikut:

Tabel 9. Data Nama User dan Preferensi Pasar Saham untuk Percobaan Backtest dan Forward Test

\begin{tabular}{cc}
\hline Nama User & Preferensi Pasar Saham \\
\hline Ash & ASII \\
Bob & JKSE \\
Chris & ASII \\
Dave & JKSE \\
Evan & JKSE \\
\hline
\end{tabular}

Proses pengujian untuk program notifikasi dibagi menjadi 3, yaitu pengujian backtest tahap 1, pengujian backtest tahap 2, dan pengujian forward test. 
Kedua pengujian backtest dilakukan pada tanggal 2 Januari 2018 hingga 6 Januari 2018 pada jam 14.00 bersamaan dengan hasil uji coba sebagai berikut:

Tabel 10. Hasil Pengujian Backtest ke-1 Program Notifikasi

\begin{tabular}{|c|c|c|c|c|c|c|c|c|}
\hline \multirow{2}{*}{ Tanggal Analisa } & \multirow{2}{*}{$\begin{array}{c}\text { Kondisi Program } \\
\text { Notifikasi }\end{array}$} & \multicolumn{2}{|c|}{$\begin{array}{c}\text { Jenis Sinyal } \\
\text { untuk Pasar Saham }\end{array}$} & \multicolumn{5}{|c|}{ Pengiriman Notifikasi ke User } \\
\hline & & ASII & JKSE & Ash & Bob & Chris & Dave & Evan \\
\hline 2 Januari 2018 & Non aktif & Hold & Hold & - & - & - & - & - \\
\hline 3 Januari 2018 & Aktif & Sell & Hold & $\checkmark$ & - & $\checkmark$ & - & - \\
\hline 4 Januari 2018 & Aktif & Hold & Sell & - & $\checkmark$ & - & $\checkmark$ & $\checkmark$ \\
\hline 5 Januari 2018 & Non Aktif & Hold & Hold & - & - & - & - & - \\
\hline 6 Januari 2018 & Aktif & Buy & Buy & $\checkmark$ & $\checkmark$ & $\checkmark$ & $\checkmark$ & $\checkmark$ \\
\hline \multicolumn{9}{|c|}{ Tabel 11. Hasil Pengujian Backtest ke-2 Program Notifikasi } \\
\hline \multirow[t]{2}{*}{ Tanggal Analisa } & $\begin{array}{l}\text { Kondisi } \\
\text { Program }\end{array}$ & $\begin{array}{r}\text { Jen } \\
\text { untuk I }\end{array}$ & $\begin{array}{l}\text { yal } \\
\text { Saham }\end{array}$ & \multicolumn{5}{|c|}{ Pengiriman Notifikasi ke User } \\
\hline & Notifikasi & ASII & JKSE & Ash & Bob & Chris & Dave & Evan \\
\hline 2 Januari 2018 & Non aktif & Hold & Hold & - & - & - & - & - \\
\hline 3 Januari 2018 & Non aktif & Hold & Hold & - & - & - & - & - \\
\hline 4 Januari 2018 & Non aktif & Hold & Hold & - & - & - & - & - \\
\hline 5 Januari 2018 & Non aktif & Hold & Hold & - & - & - & - & - \\
\hline 6 Januari 2018 & Non aktif & Hold & Hold & - & - & - & - & - \\
\hline
\end{tabular}

Pada pengujian forward test, program akan membuat prediksi harga pasar saham secara real dimana program akan dijalankan pada jam 06.40 setiap hari dimulai dari tanggal 4 Juni 2018 sampai dengan tanggal 6 Juni 2018. Pengujian forward test akan dilakukan dengan menggunakan metode simple moving average dengan kriteria untuk SMA pendek menggunakan periode 2 hari, dan SMA Panjang menggunakan periode 3 hari. Berikut adalah tabeltabel hasil pengujian forward test dari program

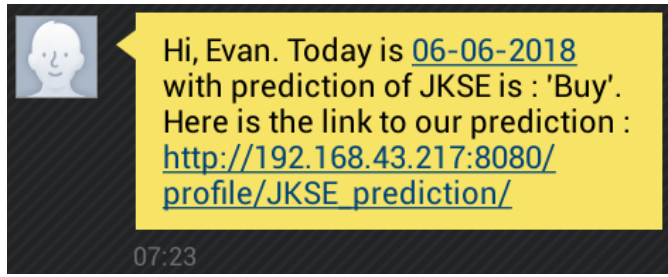

Gambar 24. Contoh format isi teks SMS yang dikirim ke smartphone milik user pada uji coba backtest pertama penghasil sinyal prediksi dan gambar bentuk SMS yang diterima oleh user:

Tabel 12. Hasil Pengujian Forward Test Program Notifikasi

\begin{tabular}{|c|c|c|c|c|c|c|c|c|}
\hline \multirow[t]{2}{*}{ Tanggal Analisa } & \multirow{2}{*}{$\begin{array}{c}\text { Kondisi } \\
\text { Program } \\
\text { Notifikasi }\end{array}$} & \multicolumn{2}{|c|}{$\begin{array}{c}\text { Jenis Sinyal } \\
\text { untuk Pasar Saham }\end{array}$} & \multicolumn{5}{|c|}{ Pengiriman Notifikasi ke User } \\
\hline & & ASII & JKSE & Ash & Bob & Chris & Dave & Evan \\
\hline 4 Juni 2018 & Non aktif & Hold & Hold & - & - & - & - & - \\
\hline 5 Juni 2018 & Aktif & Buy & Hold & $\checkmark$ & - & $\checkmark$ & - & - \\
\hline 6 Juni 2018 & Aktif & Hold & Buy & - & $\checkmark$ & - & $\checkmark$ & $\checkmark$ \\
\hline
\end{tabular}

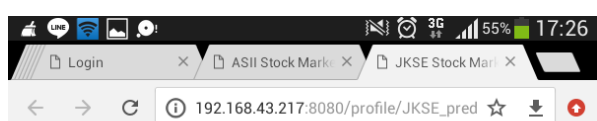

C (i) 192.168.43.217:8080/profile/JKSE pred at t

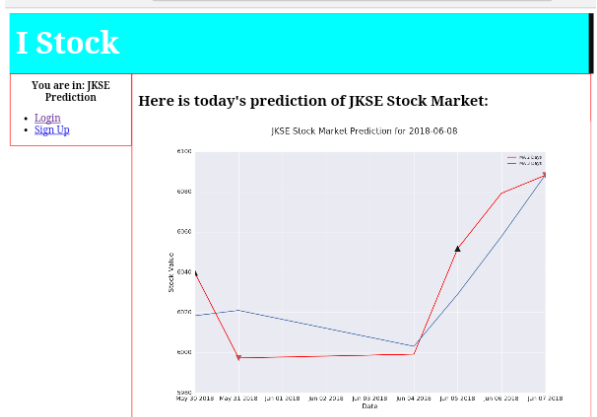

Gambar 25. Contoh tampilan hasil prediksi melalui aplikasi web browser di smartphone user pada uji coba backtest pertama
E. Pengujian Tampilan Halaman Web Hasil Prediksi

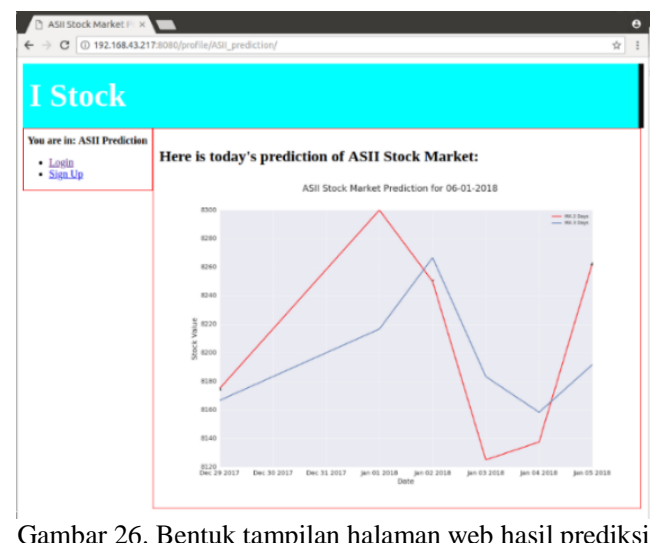

Gambar 26. Bentuk tampilan halaman web hasil prediksi 


\section{KESIMPULAN}

Beberapa hal penting yang didapat dalam pengerjaan Proyek ini adalah Raspberry Pi berhasil mengakses tabel User Profile pada database, dan melakukan proses update terhadap isi data pada tabel melalui halaman web user profile.

Raspberry Pi juga berhasil membuat prediksi trend harga naik/turun, serta menyimpan grafik hasil prediksi dalam bentuk gambar, dan mampu menjalankan program notifikasi sms ketika program penghasil sinyal mendeteksi adanya sinyal prediksi.

Raspberry Pi juga berhasil mengambil data dari tabel User Profile, dan menyusun data tersebut menjadi isi teks dari pesan SMS yang akan dikirimkan menuju user. Sistem yang dibuat juga dapat mengirimkan pesan SMS kepada para user menggunakan program notifikasi sesuai dengan kriteria profil data mengenai user dan trigger dari program penghasil sinyal.

Sistem memerlukan waktu selama 13 detik untuk mengirimkan SMS kepada satu user, sehingga dapat disimpulkan bahwa sistem dapat mengirimkan SMS kepada 266 user dalam waktu 1 jam.

Namun, sistem memiliki kelemahan dimana setiap user hanya dapat memilih 1 jenis pasar saham yang ingin dianalisa oleh program analisa. Selain itu, sistem masih memiliki kelemahan pada proses pengambilan data dimana ada kemungkinan sistem tidak berhasil memperoleh data saat proses pengambilan data dari website Yahoo Finance berlangsung.

\section{DAFTAR PUSTAKA}

EFSTATHOPOULOS, G., t.thn. Python for Finance, Part I: Yahoo \& Google Finance API, pandas, and matplotlib. [Online] Tersedia: https://www.learndatasci.com/tutorials/pyt hon-finance-part-yahoo-finance-apipandas-matplotlib/ [Diakses 7 Juli 2018].

ForexSignal, 2016. Forex signals | Forex trading signals | FX trade alerts. [Online] Tersedia: https://www.forexsignal.com/

GUNASEKARAGE, A. \& POWER, M. D., 2001. The profitability of moving average trading rules in South Asian stock markets. Science Direct, 2(1), pp. 17-33.

METZ, C., 2016. The rise of the artificially intelligent hedge fund. [Online] Tersedia: https://www.wired.com/2016/01/the-riseof-the-artificially-intelligent-hedge-fund/

SIANIPAR, R. H. \& WADI, H., 2015. Pemrograman Python : Teori dan Implementasi. Bandung: Informatika. 